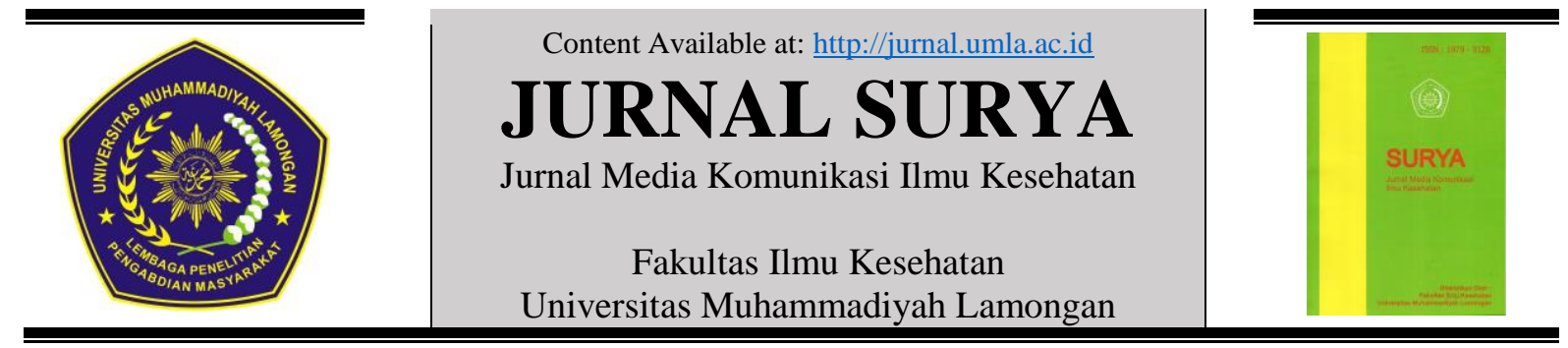

\title{
Dampak Penggunan Dot terhadap Sindrom Early Childhood Caries pada Anak Usia 3-6 Tahun di TK Nurul Huda Desa Gedongboyountung Kec. Deket Kab. Lamongan tahun 2020 \\ Asyaul Wasiah \\ Prodi D-III Kebidanan, Sekolah Vokasi, Universitas Islam Lamongan
}

\section{ARTIKEL INFO}

\section{Article History:}

SM at 14-05-2020

$R V$ at $15-05-2020$

$P B$ at 25-06-2020

\section{Kata Kunci: \\ Dot \\ Early Childhood Carries \\ Anak}

Korespondensi Penulis: asyaulwasiah@unisla.ac.id

\begin{abstract}
ABSTRAK
Background: Minum susu menggunakan dot menjelang tidur mulai menjadi kebiasaan yang sering kita jumpai. Padahal kebiasaan itu akan beresiko pada gigi anak. pada saat tidur kandungan gula dari minuman akan tersimpan dan menggenang lama di dalam mulut. Dari situlah bakteri akan tumbuh subur pada lubang gigi. Hal seperti itulah gigi anak menjadi berlubang. Sindrom tersebut di dalam medis disebut nursing bottle caries atau Early Childhood Caries.
\end{abstract}

Objectives: Tujuan penelitian ini untuk mengetahui Dampak Penggunan Dot Terhadap Sindrom Early Childhood Caries pada Anak usia 3-6 tahun di TK Nurul Huda Desa. Gedongboyountung Kec. Deket Kab. Lamongan.

Design: Desain penelitian menggunakan metode penelitian deskriptif analitik dengan menggunakan rancangan cross sectional study. Populasinya adalah semua murid di TK Nurul Huda yaitu sebanyak 54 anak. Sampel dipilih secara Purposive Sampling. Analisa data terdiri dari a). Analisa Univariat untuk mengetahui distribusi frekuensi dari setiap variable independent, b) Analisa Bivariat untuk mengetahui hubungan antara variable independent. Pengujian analitik dengan uji chi-square $(\alpha=0.05)$.

Results: Hasil uji chi-square test di atas didapatkan nilai signifikansi p-value sebesar 0.000. Karena nilai signifikansi $0.000<(0.05)$ maka $\mathrm{H}_{0}$ ditolak $\mathrm{H}_{1}$ diterima artinya ada Dampak Penggunan Dot Terhadap Sindrom Early Childhood Caries pada Anak usia 3-6 tahun di TK Nurul Huda Desa. Gedongboyountung Kec. Deket Kab. Lamongan.

Conclusions: Dapat menambah pengetahuan dan wawasan orangtua mengenai pola asuh orangtua yang tidak tepat dalam pemberian susu botol terhadap terjadinya early chilhood caries. Serta memberikan masukan agar diadakan program penyuluhan kesehatan rongga mulut di kalangan orangtua, anak dan guru sekolah agar langkah pencegahan terhadap karies bisa dilakukan sejak dini. 
PENDAHULUAN

Early childhood caries (ECC) atau karies dini adalah penyakit rampan gigi yang paling banyak menyerang anak-anak. Menurut American Dental Association (ADA), ECC ditandai dengan satu atau lebih kerusakan gigi, baiklesi dengan kavitas atau tanpa kavitas, kehilangan gigi akibat karies,atau penambalan permukaan gigi sulung pada usia prasekolah antara usia lahir hingga 71 bulan.

Minum susu menggunakan dot menjelang tidur mulai menjadi kebiasaan yang sering kita jumpai. Entah malam atau siang. Anak yang sudah memasuki umur 2 tahun para ibu mencari trik menyapih anak dari minum ASI ke susu formula. Bahkan dari umur 12 bulan sudah diajarkan minum menggunakan dot. Kebiasaan itu juga digunakan para ibu-ibu yang sibuk bekerja.

Organisasi kesehatan dunia(WHO) pada tahun 2013 menyatakan angka kejadian karies gigi pada anak masih sebesar $60-90 \%$. Penelitian taverud menunjukkan bahwa prevalensi karies gigi pada anak berusia satu tahun sebesar 5\%, anak usia dua tahun sebesar $10 \%$, anak usia tiga tahun sebesar $40 \%$, anak usia empat tahun sebesar 55\%, dan anak usia lima tahun sebesar $75 \%$. Dengan demikian golongan umur balita atau usia dini merupakan golongan rawan terjadinya karies gigi.

Prevalensi karies di Indonesia mencapai $90 \%$ dari populasi anak balita.Pada tahun 2017 menunjukkan bahwa karies gigi telah mengalami peningkatan khususnya pada anak yaitu dari $38 \%$ dimana pada anak usia 2-5 tahun meningkat $10,4 \%$ dari karies yang ditemukan (Riset KesehatanDasar (Riskesdas, 2017)).

Berdasarkan hasil wawancara awal peneliti dengan 10 orang tua (ibu) anak yang datang di sekolah mengatakan bahwa anaknya selalu di berikan susu dengan menggunakan botol, serta semua anaknya mengalami permasalahan kesehatan gigi dan mulut.

Sebenarnya baik dan praktis menggunakan dot. Tetapi kebiasaan itu akan beresiko pada gigi anak. pada saat tidur kandungan gula dari minuman akan tersimpan dan menggenang lama di dalam mulut. Dari situlah bakteri akan tumbuh subur pada lubang gigi. Ditambah saat anak tidur air liur akan mengalami pengurangan. Jadi, genangan air minum mengandung gula tertahan oleh dot diantara lidah, gigi, langit-langit dan disekitar bibir. Hal seperti itulah gigi anak menjadi berlubang. Sindrom tersebut di dalam medis disebut nursing bottle caries atau Early Childhood Caries.

Kesehatan gigi dan mulut sebagai bagian dari kesehatan badan, ikut berperan dalam menentukan status kesehatan seseorang. Untuk menilai status kesehatan gigi dapat di lihat dari ada dan tidak nya penyakit gigi, di antaranya karies gigi. Karies gigi merupakan penyakit gigi yang paling banyak di temukan, meliputi semua usia dan lapisan masyarakat yang jika tidak di ketahui sejak dini dan di biarkan berlanjut dapat menjadi lebih parah. Selain itu timbul pula komplikasi yang serius berupa penyakit ginjal, jantung, saraf dan sebagainya

Berdasarkan latar belakang diatas, maka penulis tertarik untuk meneliti bagaimana Dampak Penggunan Dot Terhadap Sindrom Early Childhood Caries pada Anak usia 3-6 tahun di TK Nurul Huda Desa. Gedongboyountung Kec. Deket Kab. Lamongan Tahun 2020.

\section{METODE}

Desain penelitian ini menggunakan metode penelitian deskriptif analitik dengan menggunakan rancangan cross sectional study (study potong lintang) yaitu peneliti mempelajari hubungan antar variabel bebas dan variabel terikat.

Populasi dalam penelitian ini adalah semua murid di TK Nurul Huda yaitu sebanyak 54 anak. Sampel dipilih secara Purposive Sampling dengan kriteria inklusi : anak usia 3-6 tahun dan menggunakan susu botol

Analisa data terdiri dari a). Analisa Univariat untuk mengetahui distribusi frekuensi dari setiap variable independent, $b$ ) Analisa Bivariat untuk mengetahui hubungan antara variable independent. Dalam analisa ini dilakukan pengujian analitik dengan uji chi-square $(\alpha=0.05)$ menggunakan program Statistik Program for Social Scince (SPSS). 
HASIL PENELITIAN

Tabel 1 Distribusi frekuensi responden berdasarkan penggunanan dot

\begin{tabular}{llcc}
\hline No & Penggunaan Dot & F & $\mathbf{\%}$ \\
\hline 1 & Ya & 6 & 11,1 \\
2 & Tidak & 48 & 88,9 \\
\hline \multicolumn{2}{l}{ Total } & $\mathbf{5 4}$ & $\mathbf{1 0 0}$ \\
\hline \multicolumn{2}{l}{ Sumber : Data Primer Hasil Penelitian } \\
2
\end{tabular}

Berdasarkan tabel 1 Menunjukkan

bahwa dari 54 responden sebagian besar minum susu mengggunakan dot yaitu 48 responden $(88,9 \%)$

Tabel 2 Distribusi frekuensi responden berdasarkan kejadian sindrom ECC

\begin{tabular}{llcc}
\hline No & Sindrom ECC & F & \% \\
\hline 1 & Ya & 15 & 27,8 \\
2 & Tidak & 39 & 72,2 \\
\hline Total & $\mathbf{5 4}$ & $\mathbf{1 0 0}$ \\
\hline \multicolumn{2}{l}{ Sumber : Data Primer Hasil Penelitian } & 2020
\end{tabular}

Berdasarkan tabel 2 Menunjukkan bahwa dari 54 responden sebagian besar terjadi sindrom ECC yaitu sebanyak 39 responden $(72,2 \%)$.

Tabel 3 Tabulasi Silang Penggunaan Dot dengan Sindrom ECC

\begin{tabular}{lccccc}
\hline & & \multicolumn{3}{c}{ Sindrom ECC } & Total \\
\cline { 3 - 5 } & & \multicolumn{2}{c}{ Tidak } & Ya & \\
\hline Penggun- & Tidak & F & 6 & 0 & 6 \\
aan Dot & & $\%$ & 100 & 0 & 100 \\
\cline { 2 - 5 } & Ya & F & 9 & 39 & 48 \\
& & $\%$ & 18,7 & 81,3 & 100 \\
\hline Total & & F & 15 & 39 & 54 \\
& & $\%$ & 27,8 & 72,2 & 100 \\
\hline
\end{tabular}

Sumber : Data Primer Hasil Penelitian 2020

Berdasarkan tabel 3 menunjukkan bahwa dari 54 responden sebagian besar anak yang menggunakan dot akan mengalami kejadian sindrom ECC yaitu 39 responden $(81,3 \%)$.

Tabel 4 Uji analisis Dampak Penggunan Dot Terhadap Sindrom Early Childhood Caries pada Anak usia 3-6 tahun. Asymp. Exact Bneggunakan botol.

Value df Sig. (2- Sig. (2- Sig. (1- Minum susu dengan menggunakan sided) sided) bedel sampai tertidur adalah cara yang tidak

\begin{tabular}{|c|c|c|c|c|c|}
\hline & lue & & $\begin{array}{l}\text { Sig. }(2- \\
\text { sided })\end{array}$ & $\begin{array}{l}\text { Sig. }(2- \\
\text { sided) }\end{array}$ & $\begin{array}{l}\text { Sig. (1- Minum susu dengan menggunakan } \\
\text { bidedl sampai tertidur adalah cara yang tidak }\end{array}$ \\
\hline Pearson Chi-Square & $17.550^{\mathrm{a}}$ & 1 & .000 & & baik, cairan susu tersebut akan menggenangi \\
\hline Continuity Correction $^{\mathrm{b}}$ & 13.734 & 1 & . 000 & & rongga mulut (gigi) untuk beberapa waktu \\
\hline Likelihood Ratio & 17.484 & 1 & .000 & & (jam). Genangan susu pada rongga mulut saat \\
\hline Fisher's Exact Test & & & & .000 & $\begin{array}{l}\text { tidur } \\
.000\end{array}$ \\
\hline
\end{tabular}

Sumber : Data Primer Hasil Penelitian 2020

Pada tabel chi-square test di atas dapat diketahui bahwa nilai signifikansi pvalue sebesar 0.000 . Karena nilai signifikansi $0.000<(0.05)$ maka $\mathrm{H} 0$ ditolak H1 diterima artinya ada Dampak Penggunan Dot Terhadap Sindrom Early Childhood Caries pada Anak usia 3-6 tahun di TK Nurul Huda Desa. Gedongboyountung Kec. Deket Kab. Lamongan.

\section{PEMBAHASAN}

Berdasarkan hasil Analisis data dengan menggunakan uji chi-square test di atas dapat diketahui bahwa nilai signifikansi p-value sebesar 0.000. Karena nilai signifikansi $0.000<(0.05)$ maka H0 ditolak H1 diterima artinya ada Dampak Penggunan Dot Terhadap Sindrom Early Childhood Caries pada Anak usia 3-6 tahun di TK Nurul Huda Desa. Gedongboyountung Kec. Deket Kab. Lamongan .

Hasil uji silang juga menunjukkan bahwa dari 54 responden sebagian besar anak yang menggunakan dot akan mengalami kejadian Sindrom Early Childhood Caries yaitu 39 responden $(81,3 \%)$.

Indeks karies pada anak yang mengkonsumsi susu botol adalah 5,3 menurut WHO indeks ini tergolong dalam kategori tinggi. Tingginya indeks karies pada anak yang mengkonsumsi susu botol dipengaruhi oleh kebiasaan minum susu formula menggunakan media berupa dot botol. Pemberian susu formula menggunakan botol dengan durasi yang lama dan kebiasaan minum susu formula dengan dot hingga anak tertidur serta oral hygiene yang buruk. Hal ini dikarenakan terlambatnya tindakan pencegahan karies setelah anak minum susu

\begin{tabular}{lcl}
\hline $\begin{array}{l}\text { Linear-by-Linear } \\
\text { Association }\end{array}$ & $17.225 \quad 1 \quad .000$ \\
\hline $\begin{array}{l}\text { N of Valid Cases } \\
\text { b }\end{array}$ & 54 \\
\hline cells $(50,0 \%)$ have expected count less than 5. The minimum \\
expected count is 1,67.
\end{tabular}


difermentasikan oleh bakteri menjadi asam, $\mathrm{pH}$ plak menjadi dibawah 5 dalam waktu 1-3 menit. Semakin lama dan sering anak mengkonsumsi susu botol, maka potensi untuk terjadinya karies makin tinggi. Gupte (2004) mengungkapkan bahwa terjadinya karies gigi diawali oleh proses demineralisasi enamel gigi. Konsumsi susu botol yang sering dan lama ditambah anak mengkonsumsi makanan manis yang melekat di gigi dan anak tersebut tidak menggosok gigi, maka kondisi $\mathrm{pH}$ plak tetap asam sehingga dapat merusak struktur jaringan keras gigi. Menurut Yunanto (2016) proses terjadinya karies dapat terjadi dalam jangka waktu sekitar 6-48 bulan untuk berkembang menjadi kavitas yg cukup bervariasi.

Karies pada gigi sulung juga disebabkan karena terpaparnya gigi oleh cairan manis dalam waktu yang lama. Lamanya cairan tersebut berada di rongga mulut, seperti ketika anak tertidur sambil menghisap dot yang berisi susu ataupun cairan manis lainnya menggunakan botol yang akan memperparah terjadinya karies. Kondisi yang memperparah terjadinya karies pada anak adalah karena ketidakpahaman orang tua terhadap penyebab utama terjadinya karies tersebut.

Langkah - langkah mencegah terjadinya karies adalah dengan minum susu tanpa botol, minum air putih yang banyak, membiasakan menggosok gigi secara teratur sehabis mengkonsumsi makanan manis dan makan makanan yang berserat. Pendapat ini didukung oleh penelitian Suharja (2016) yang menyimpulkan bahwa terdapat perbedaan frekuensi karies pada anak yang memiliki kebiasaan menggosok gigi setiap hari dengan kelompok anak yang tidak menggosok gigi setiap hari.

Indeks karies pada anak yang mengkonsumsi susu tanpa botol adalah 3,4 menurut WHO indeks ini tergolong dalam kategori sedang. Hasil penelitian ini menyatakan bahwa kerusakan gigi lebih tinggi pada anak yang mengkonsumsi susu menggunakan botol dibandingkan tanpa botol. Jumlah decay dan extraction lebih besar pada anak yang mengkonsumsi susu botol dibanding tanpa botol, hal ini menunjukkan anak yang minum susu botol dalam waktu yang lama dan minum susu hingga tertidur lebih berisiko mengalami Nursing Mouth
Caries (NMC). Penelitian ini sesuai dengan yang diungkapkan oleh Nelson (2012) yang menyatakan bahwa anak yang mengkonsumsi susu botol merupakan faktor predisposisi rampan karies.

Gigi yang terkena kerusakan karies umumnya adalah gigi anterior rahang atas karena genangan air susu akan lebih berkontak dengan gigi-gigi rahang atas. Timbunan susu dalam mulut merupakan media yang baik untuk difermentasikan oleh bakteri streptococcus mutans sehingga menghasilkan asam yang merusak gigi.10 Gigi-gigi rahang bawah jarang terjadi kerusakan karena tertutup oleh lidah dan saliva dan terdapat glandula saliva, sehingga meningkatkan self cleansing yang akan menghambat pembentukan plak serta mengatur $\mathrm{pH}$ rongga mulut. Pendapat ini sesuai dengan hasil penelitian Rahmi (2011) bahwa kerusakan akan diperparah jika penggunaan dot dalam pemberian susu diberikan sepanjang malam atau sampai anak tertidur karena selama tidur produksi saliva sangat lambat. Anak yang minum susu tanpa menggunakan botol risiko mengalami kerusakan gigi lebih rendah, karena anak minum susu dengan posisi duduk dan cairan susu yang diminum akan langsung di telan, sehingga cairan susu tersebut tidak menggenang di gigi.

Pemberian susu menggunakan botol dan tanpa botol tidak mempengaruhi filled. Jumlah filled lebih besar pada anak yang mengkonsumsi susu tanpa botol dikarenakan kemungkinan adanya kesadaran orang tua dalam menjaga kesehatan gigi anak. Susu formula yang diminum kemungkinan besar dapat mempengaruhi terjadinya karies gigi, karena produk susu tersebut mengandung karbohidrat. Kandungan karbohidrat pada susu merupakan media yang baik untuk difermentasikan bakteri streptococcus mutans menjadi asam yang akan merusak struktur jaringan keras gigi, pada keadaan tersebut jumlah aliran saliva menurun, kualitas saliva mengental, $\mathrm{pH}$ plak menurun sehingga efek self cleansing berkurang dan akan meningkatkan kualitas bakteri kariogenik. Pola konsumsi susu formula yang salah dapat memperparah terjadinya karies. Pendapat ini didukung oleh Supariasa (2013) bahwa tidak ada hubungan yang bermakna antara kandungan karbohidrat pada susu dengan 
kejadian karies pada anak, tetapi semua kandungan karbohidrat pada susu formula dapat menyebabkan terjadinya karies pada anak.

Karies gigi tidak terjadi jika proses demineralisasi berlangsung lambat sementara proses remineralisasi cukup aktif, selain itu kemungkinan lainnya bisa berupa terbentuknya karies jika proses remineralisasi tidak cukup kuat untuk mengimbangi proses demineralisasi yang cepat. Kondisi remineralisasi ini dapat dicapai jika $\mathrm{pH}$ dinetralisir atau melalui simpanan ion-ion kalsium dan fosfat yang ada dalam saliva, sehingga terjadi remineralisasi. Kemungkinan yang dapat terjadi bisa berupa terhentinya perkembangan karies gigi jika kemampuan remineralisasi cukup kuat untuk menanggulangi proses demineralisasi.

Pengetahuan orang tua dalam hal ini sangat berpengaruh. Menurut Afrilina et al (2006) bahwa pengetahuan orang tua yang tepat mempengaruhi perilaku kesehatan keluarga dalam meningkatkan kesehatan, khususnya kesehatan gigi dan mulut anak dan status ekonomi yang baik mendukung keluarga dalam memilih sarana pelayanan kesehatan yang baik. Hal ini menyebabkan status kesehatan anak tetap terjaga dan terhindar dari risiko karies yang parah.

Berdasarkan hal tersebut, diharapkan orang tua lebih memperhatikan kesehatan gigi anak terutama pada saat pemberian susu menjelang tidur. Pemberian susu yang paling baik adalah dengan menggunakan gelas. Menurut Rahmi (2011) jika anak terpaksa minum susu menggunakan botol usahakan dalam posisi tegak dan terjaga. Apabila anak tertidur segera ambil botolnya dan mulut anak dibersihkan. Lakukan upaya pencegahan dengan menyikat gigi serta menggunakan pasti gigi mengandung fluor dengan jumlah yang tepat.

Dapat disimpulkan bahwa indeks karies anak yang mengkonsumsi susu botol lebih tinggi dibanding tanpa botol. Indeks karies pada anak yang mengkonsumsi susu botol sebesar 5,3 yang termasuk dalam kategori tinggi. Indeks karies anak yang mengkonsumsi susu tanpa botol sebesar 3,4 termasuk dalam kategori sedang.
KESIMPULAN

Sindroma kerusakan gigi yang parah yang terjadi pada bayi dan anak-anak, berkembang dengan cepat dan mengakibatkan gangguan kesehatan yang berkepanjangan pada anak disebut sebagai ECC. Penyebab ECC multi faktor, antara lain kebersihan gigi dan mulut yang tidak terpelihara dengan baik, adanya penyakit sistemik yang diderita anak seperti malnutrisi, asma,infeksi rekuren, penyakit infeksi kronik, penggunaan obatobatan seperti antihistamin, benzodiazepam, antiemetik, ekspektorandan antispsmodik, serta penggunaan botol untuk minum susu pada malam hari.

Solusi pencegahan ECC ini adalah perhatian dan pengetahuan orang tua dalam hal kebersihan dan kesehatan gigi sehingga dapat membersihkan dan membiasakan anak menjaga kesehatan mulut dan giginya. Kebersihan mulut dan penggunaan fluoride penting untuk mencegah kerusakan gigi lebih lanjut. Apabila ECC sudah terlanjur parah, dokter gigi harus dapat menanganinya dengan perawatan yang maksimal dan tetap memberikan perawatan pencegahan.

\section{DAFTAR PUSTAKA}

Afrilina, Gralianti, 2006, 75 Masalah Gigi Anak Dan Solusinya. Jakarta: Gramedia

Gupte, S. 2004. Pedoman Perawatan Anak. Jakarta: Pustaka Populer Obor

Nelson, 2012, definisi rampan karies .http//www.Rampankaries.co.id. diakses tanggal 10 februari 2020.

Rahmi, 2011. Minum Susu Botol Picu Karies Gigi Anak. Jakarta: IDAI

Suharja, E.S., 2016, Efektifitas Pendidikan Kesehatan Gigi Antara Metode Ceramah Dengan Modul Dan Tanpa Modul Terhadap Pengetahuan, Persepsi, Motivasi, Perilaku Dan Kesehatan Gigi Dan Mulut Santri Usia 12-14 Tahun, Tesis, Program Pascasarjana UGM, Yogyakarta. 
Supariasa I.D.N., dkk. 2013. Penilaian Status Gizi (Edisi Revisi). Jakarta: Penerbit Buku Kedokteran EGC

Yunanto, Ari. 2016. Buku Ajar Neonatologi. Jakarta: IDAI 